\title{
PLATYHARPES WHITTINGTON, 1950, A SYNONYM OF HIBBERTIA JONES AND WOODWARD, 1898
}

SIR,-In my recent (1950) monograph of the British Trilobites of the family Harpidae I erected a new genus, Platyharpes, the genotype being Harpes flanaganni Portlock, 1843. In 1898 (pl. xxv, figs. 8a, 8b) Jones and Woodward published pictures of a supposed new crustacean genus and species, Hibbertia orbicularis, believed to be from the Lower Carboniferous of Scotland. The description was published in the following year (Jones and Woodward, 1899a, 390-393, pl. xv, fig. $4 ; 1899,205-8)$. Withers (1929) recognized that the specimen upon which Hibbertia orbicularis was founded was not a crustacean, but should be referred to the Middle Ordovician trilobite Harpes flanaganni Portlock, and that it probably came from the type locality in Northern Ireland and not from Scotland. I have examined the specimen and expressed agreement with Withers' conclusions (Whittington, 1950, p. 36). Withers also stated that Hibbertia should become a synonym of Harpes Goldfuss, 1839. When I selected Harpes flanaganni as the type of a new genus I should not have made the new name Platyharpes but revived Hibbertia. since the genotype is the same. In stating that Platyharpes is a synonym of Hibbertia it should be pointed out that this synonomy is subjective, since the specimen upon which Jones and Woodward founded their genus is not the diplotype, i.e. the lectotype of Hibbertia flanaganni (Portlock, 1843).

\section{Museum of Comparative ZOOLOGY, HaRVARd College, Cambridge, Mass. \\ 9th June, 1950.}

H. B. Whittington.

\section{REFERENCES}

JoNes, T. R., and WoODWARD, H., 1898-9. A Monograph of the British Palacozoic Phyllopoda (Phyllocarida, Packard). Palaeontographical Soc., London.

1899a. Contributions to Fossil Crustacea. Geol. Mag., xxxvi, 388-395.

Whitrington, H. B., 1950. A Monograph of the British Trilobites of the Family Harpidae. Palaeontographical Soc., London.

Withers, T. H., 1929. The supposed Phyllocarid genus Hibbertia. Ann. Mag. Nat. Hist., 10, iv, p. 288.

\section{CHALK ROCK OF DORSET-MORE EVIDENCE OF SALT ?}

SIR,-W With reference to Mr. J. A. Robbie's interesting account of Turonian chalk at Winterbourne Abbas containing Albian and Cenomanian pebbles, ${ }^{1}$ an alternative source of the coarse material may be suggested.

During 1948 we observed that the almost circular anticlinal inlier of Jurassic rocks at Compton Valence, $1 \frac{1}{2}$ miles north-west of Winterbourne, differed markedly from other south-country anticlines in pattern and might well be due to a non-emergent salt plug. In view of the salt-bearing marl proved in the Keuper of the Puriton borehole, 33 miles further north-west, this suggestion is not unreasonable. It will be recalled that $G$. M. Lees and P. T. Cox have already expressed the view that the tectonics of South Dorset are most readily explicable by the presence of a plastic series at depth.

Preliminary field examination confirmed that the sharply upturned dips recorded by H.M. Geological Survey in the Upper Greensand and Chalk near the Jurassic contact could have been produced by diapiric movement. It also showed that there was little hope of adding to data on the Jurassic (known only to be in part selenitic clay, presumed Oxfordian) without deep pitting or boring.

Through the courtesy of the landowner, Mr. W. D. Chick, the D'Arcy

1 Geol. Mag., Ixxxvii, 1950, 209-213. 
Exploration Company was able to use a shallow drilling outfit to sink a borehole on the crest of the structure for additional information. While this was in progress a small outcrop of Fullers Earth Rock with the characteristic brachiopod fauna was located near by, and the boring passed from just below this level into normal Upper Inferior Oolite, reached at 164 feet, in which operations were suspended.

Although, of course, in no way conclusive this additional evidence tended to support our view that the Compton Valence structure is of salt dome type for the nearest main outcrop shows Cretaceous resting upon Oxfordian and Kimmeridgian rocks. It consequently provides a good alternative source for the very local Winterbourne Abbas conglomerate. As Mr. Robbie recognized, there are several difficulties about derivation of the pebbles from the Abbotsbury anticline, whereas a slight heave of deeply buried salt much nearer at Compton Valence might well produce just this effect.

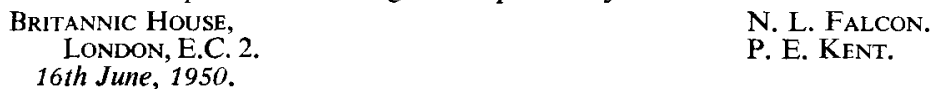

\section{SYNONYMOUS HOMONYMY AT GENERIC LEVEL}

Sir,-Apropos Mr. L. Bairstow's letter (Geol. Mag., 1xxxvii, 1950, p. 226), the following seems to be a genuine case, and it illustrates an unusual mode of operation of the rules governing type designation.

The ammonite genus Blanfordia Uhlig 1905, non Adams 1863, was renamed Blanfordiceras by Cossmann (1907, Revue crit. Paléozool., xi, 64), but no type was designated by either Uhlig or Cossmann. In 1924 L. F. Spath (Pal. Indica, ix, mem. 1, p. 16) wrote "Blanfordiceras n.n. olim 'Blanfordia' preoccupied ". In 1923 the combination Blanfordiceras wallichi had appeared in another paper by Dr. Spath (Quart. Journ. Geol. Soc., lxxix, 302) without explanation or indication that the generic name was new, and in 1925 (Mon. Hunterian Mus. Glasgow, Coll. Foss. Somaliland, p. 145) appeared "Blanfordiceras Spath", with a footnote stating that "the type is Bl. wallichi (Gray) [1830], pl. C, fig. 3 ". Thus, it appears that Blanfordiceras Spath 1923 is an independent synonymous homonym of Blanfordiceras Cossmann 1907, both being nomina nova for Blanfordia Uhlig 1905.

Further, since Ammonites wallichi Gray is type species by monotypy of Blanfordiceras Spath 1923, by Article 30, II, f, A. wallichi Gray is also type species of Blanfordia Uhlig (of which it was a syntype), and therefore also of the valid Blanfordiceras Cossman 1907.

SedgWick Museum,

CAMBRIDGE.

June, 1950.

W. J. ARkell.

\section{REVIEWS}

Stratigraphy and Paleontology of the Brownsport Formation (Silurian) OF Western Tennessfe. By T. W. Amsden. Peabody Museum of Natural History, Bulletin 5; Yale University Press (London: Geoffrey Cumberlege), 1949. pp. viii +126 , with 30 figures and 34 plates. Price $40 s$.

Some forty pages are devoted to the stratigraphy of the Brownsport Formation and to its correlation, the remainder to specific description of the fauna. A general Niagaran age can be assigned, but closer correlation leads to the view that the Brownsport strata are unrepresented in the Niagaran succession of central and western New York. The proportion of new species described is high, particularly among corals and brachiopods, and a new genus of Tabulate coral (Romingerella) is proposed. The illustrations are well-reproduced and the thesis constitutes a notable addition to the faunal lists of the Niagaran.

O. M. B. B. 